\title{
Influence of diet on the risk of developing endometriosis
}

\author{
Joanna Jurkiewicz-Przondziono ${ }^{1,2}$, Magdalena Lemm³, Anna Kwiatkowska-Pamuła4, \\ Ewa Ziółko ${ }^{4}$, Mariusz K. Wójtowicz ${ }^{2}$ \\ ${ }^{1}$ PhD student from the Department and University Ward of Internal Medicine, School of Public Health in Bytom, \\ Medical University of Silesia, Poland \\ ${ }^{2}$ Mother and Child Health Center in Zabrze, Poland \\ ${ }^{3}$ Department of Obstetrics and Gynaecology, Medical University of Silesia, Poland \\ ${ }^{4}$ Department and University Ward of Internal Medicine, School of Public Health in Bytom, Medical University of Silesia, Poland
}

\begin{abstract}
Endometriosis is a hormone-dependent chronic inflammatory disease characterized by the presence of endometrium beyond the uterine cavity. The disease affects $5-15 \%$ of women of child-bearing age, $30-50 \%$ of whom suffer from infertility. Understanding the role of dietary factors in the development of endometriosis is critical to development of effective dietary instructions for prevention. Existing studies concerning nutrition and endometriosis suggest that diet is a potentially modifiable risk factor for endometriosis. Fruits and vegetables, fish oils, dairy products rich in calcium and vitamin $D$, and Omega-3 fatty acids are likely connected with a lower risk of developing endometriosis. Risk factors that increase the risk of endometriosis include consumption of products rich in trans-unsaturated fatty acids, consumption of fats generally, and consumption of beef and other kinds of red meat and alcohol. Currently, there are no clear correlations between particular food products and the risk of endometriosis. Further research is needed in order to fully understand the influence of consumed food products on the risk of development of this disease.
\end{abstract}

Key words: endometriosis, diet, risk factors, nutrition

Ginekologia Polska 2017; 88, 2: 96-102

\section{INTRODUCTION}

Endometriosis is a hormone-dependent chronic inflammatory disease. It is characterized by the appearance of the mucosa of the uterine body, including submucosal and glandular cells, beyond the uterine cavity [1]. Inflammatory foci are usually located in the pelvis minor, ovaries, fallopian tubes, cul-de-sac, uterosacral ligaments, and vesicouterine pouch. However, appearance in Caesarean section scars, lungs, intestines, or appendix has been also described [2]. Endometriosis affects $5-15 \%$ of women of child-bearing age [3], 30-50\% of whom suffer from infertility [4]. Three types of endometriosis have been described, including peritoneal, ovarian, and deep infiltrating endometriosis [4]. Immune, endocrine, genetic, and anatomical disorders have been mentioned as risk factors $[5,6]$, but the etiology of the disease is not fully understood [7].
According to the Polish Gynecological Society, the standard method of diagnosing endometriosis is laparoscopy (it is suggested to collect a specimen for histopathological examination) or making the foci of endometriosis visible via colposcopy preceded by interview and physical examination [4]. The chief complaint of women suffering from endometriosis is pain during sexual intercourse, urination, or defecation. Abdominal pain may occur in cycles or it can be constant [8]. Other coexisting symptoms include dysmenorrhea, menstrual pains with irregular bleeding and premenstrual spotting, defecation disorders (e.g., constipation, diarrhea, bleeding), pollakiuria, blood in the urine, and infertility [5]. Endometriosis influences the physical, mental, and social wellbeing of women [6]. The average cost of treatment per patient calculated across 10 countries was 9.579 euro per year [9].

Corresponding author:

Joanna Jurkiewicz-Przondziono

Mother and Child Health Center in Zabrze

Zamkowa St. 4, 41-803 Zabrze, Poland

tel.: 603995867

e-mail:jjurkiewicz@szpitalzabrze.pl 
In addition to traditional forms of treatment for endometriosis, including surgical treatment and pharmacotherapy, increasing attention is being devoted to the supplementary treatment.

\section{THE ROLE OF DIET IN ENDOMETRIOSIS}

The current scientific evidence suggests that the diet and lifestyle may influence the presence of inflammation in the body, estrogen activity, menstrual cycle, and prostaglandin metabolism. As such, diet and lifestyle can also impact the risk of developing endometriosis $[10,11]$. There are a number of plausible theories linking endometriosis to dysmenorrhea, defined as painful menstrual cramps coming from the uterus in a normal pelvis. In developing countries the incidence of dysmenorrhea ranges from $45 \%$ to $90 \%$ $[12,13]$ and it is frequently observed in women suffering from endometriosis. This symptom turned out to be an important predictor in women suffering from infertility [14, 15]. Therefore, it is possible that a large number of patients with dysmenorrhea may suffer from undiagnosed endometriosis. One of the possible pathogenic factors affecting both endometriosis and dysmenorrhea is prostaglandin levels. Omega- 6 fatty acids derived from the diet are the precursors of the proinflammatory prostaglandins PGE2 and PGF2a that probably increase uterine cramps and cause the painful symptoms. However, PGE3 and PGE3a derived from the Omega-3 fatty acids were linked to reduced inflammation and thus, lesser pain [16].

High levels of estrogen may be another risk factor for developing endometriosis. Research has demonstrated a connection between diet and the incidence of the estrogen-dependent diseases (e.g. breast and endometrial cancer). We can therefore assume that dietary impact blood estrogen levels may also play a role in the etiology of endometriosis $[17,18]$.
Food may also contain chemical compounds from contaminated environments, especially chlorinated hydrocarbons including polychlorinated biphenyls (PCBs). Such compounds tend to bioaccumulate in lipids contained particularly in meat, liver, and dairy products. Similarly, pesticides can be consumed together with contaminated fruits and vegetables. The above compounds can also be counted among the risk factors for endometriosis $[19,20]$.

\section{PURPOSE}

The aim of this paper is to evaluate the literature to examine whether diet correlates with the risk of developing endometriosis and/or the occurrence of dysmenorrhea, evaluate dietary factors for role in decreasing or increasing the risk for endometriosis, and, if possible, create effective dietary instructions for women suffering from endometriosis. Results of studies incorporated into the review are presented in the tables showing research type, group size, study results, and level of evidence.

\section{FRUITS, VEGETABLES, AND DIETARY FIBER}

Two studies have examined the relationship between portions of fruits and vegetables consumed during a week and the risk of developing endometriosis [21, 24]. In a case-control study by Parrazinni et al. (2004) the risk of the disease was significantly reduced in women who ate large amounts of green vegetables and fresh fruits (Tab. 1) [21]. In contrast, in a case-control study conducted by Trabert et al. in 2011 found that an increased number of portions of fruits consumed daily was connected with a higher risk of endometriosis, but no connection between endometriosis risk and vegetable consumption was observed. A study conducted in 2011 by Savaris and Amaral [23] showed that consumption of the dietary fiber was connected with higher endometriosis risk.

\begin{tabular}{|c|c|c|c|c|c|c|}
\hline \multirow{2}{*}{ Author [ref] } & \multirow{2}{*}{ Study type } & \multirow{2}{*}{ Subjects } & \multicolumn{3}{|c|}{ Findings } & \multirow{2}{*}{$\begin{array}{l}\text { Level of } \\
\text { evidence* }\end{array}$} \\
\hline & & & Vegetables & Fruits & Fiber & \\
\hline $\begin{array}{l}\text { Parazzini et al., } \\
2004 \text { [21] }\end{array}$ & $\begin{array}{l}\text { Case-control } \\
\text { study }\end{array}$ & $\begin{array}{l}\text { The experimental group }(n=504) \text { consisted of women } \\
\text { aged } 20-65 \text { years with the diagnosed endometriosis and } \\
\text { the control group }(n=504) \text { consisted of women aged } \\
20-61 \text { years with no gynecological disorders }\end{array}$ & $\downarrow$ & $\downarrow$ & & III \\
\hline $\begin{array}{l}\text { Trabert et al., } \\
2010 \text { [22] }\end{array}$ & $\begin{array}{l}\text { Case-control } \\
\text { study }\end{array}$ & $\begin{array}{l}\text { The experimental group }(n=284) \text { consisted of women } \\
\text { aged } 20-65 \text { years diagnosed with endometriosis and the } \\
\text { control group }(n=660) \text { consisted of healthy women }\end{array}$ & $\begin{array}{l}\text { No influence } \\
\text { found }\end{array}$ & $\uparrow$ & & III \\
\hline $\begin{array}{l}\text { Savaris and } \\
\text { Amara } 2011 \text { [23] }\end{array}$ & $\begin{array}{l}\text { Case-control } \\
\text { study }\end{array}$ & $\begin{array}{l}\text { The experimental group }(n=25) \text { consisted of women } \\
\text { with stage I-IV endometriosis and the control group } \\
(n=20) \text { consisted of women with no gynecologial } \\
\text { disorders }\end{array}$ & & & $\uparrow$ & III \\
\hline
\end{tabular}


Table 2. Influence of consumption of fats, fish oils, and polyunsaturated fatty acids (PUFAs) on the risk of occurrence of endometriosis

\begin{tabular}{|c|c|c|c|c|c|}
\hline Author [ref] & Study type & Subjects & \multicolumn{2}{|c|}{ Results } & $\begin{array}{l}\text { Level of } \\
\text { evidence* }\end{array}$ \\
\hline $\begin{array}{l}\text { Britton et al., } \\
2000 \text { [28] }\end{array}$ & $\begin{array}{l}\text { Case-control } \\
\text { study }\end{array}$ & $\begin{array}{l}\text { Age:18-74 years, the experimental group ( } n=393) \text { - women with } \\
\text { benign ovarian tumors, }(n=280) \text { women with endometrial tumors; } \\
\text { Control group }(n=351) \text { - women with no diagnosed ovarian tumor } \\
\text { or endometrial tumor }\end{array}$ & \multicolumn{2}{|c|}{$\uparrow$} & III \\
\hline $\begin{array}{l}\text { Parazzini et al., } \\
2004 \text { [21] }\end{array}$ & $\begin{array}{l}\text { Case-control } \\
\text { study }\end{array}$ & $\begin{array}{l}\text { The experimental group }(n=504) \text { consisted of women aged } \\
20-65 \text { years with diagnosed endometriosis and the control group } \\
(n=504) \text { consisted of women aged 20-61 with no gynecological } \\
\text { disorders }\end{array}$ & \multicolumn{2}{|c|}{ No influence found } & III \\
\hline $\begin{array}{l}\text { Heilier et al., } \\
2006 \text { [24] }\end{array}$ & $\begin{array}{l}\text { Case-control } \\
\text { study }\end{array}$ & $\begin{array}{l}\text { The experimental group }(n=176) \text { consisted of women with } \\
\text { diagnosed endometriosis and endometrial nodules and the control } \\
\text { group }(n=88) \text { healthy women }\end{array}$ & \multicolumn{2}{|c|}{ No influence found } & III \\
\hline $\begin{array}{l}\text { Sesti et al., } \\
2007 \text { [26] }\end{array}$ & $\begin{array}{l}\text { Randomized } \\
\text { study }\end{array}$ & $\begin{array}{l}\text { Women diagnosed with endometriosis. } 4 \text { groups: post-operative } \\
\text { placebo group }(n=115), G n R H \text { therapy group }(n=42) \text {, group } \\
\text { being administered low doses of oral contraceptives }(n=40) \text {, } \\
\text { supplements ( } n=37 \text { ) }\end{array}$ & \multicolumn{2}{|c|}{ No influence found } & 1 \\
\hline $\begin{array}{l}\text { Sesti et al., } \\
2009 \text { [27] }\end{array}$ & $\begin{array}{l}\text { Randomized } \\
\text { study }\end{array}$ & $\begin{array}{l}\text { Women diagnosed with endometriosis divided into four } \\
\text { groups: placebo group ( } n=65), \mathrm{GnRH} \text {-a therapy group }(n=65) \text {, } \\
\text { group treated by continual low doses of the monophasic oral } \\
\text { contraceptives, supplements (vitamins, mineral salts, lactic acid, cod } \\
\text { liver oil) ( } n=65 \text { ) }\end{array}$ & \multicolumn{2}{|c|}{ No influence found } & 1 \\
\hline $\begin{array}{l}\text { Missmer et al., } \\
2010 \text { [11] }\end{array}$ & $\begin{array}{l}\text { Prospective } \\
\text { study }\end{array}$ & $\begin{array}{l}\text { The experimental group consisted of } n=1,199 \text { women aged } \\
25-42 \text { years diagnosed with endometriosis and the control group } \\
\text { consisted of } n=69,510 \text { healthy women }\end{array}$ & $\downarrow$ Omega-3 & $\begin{array}{c}\uparrow \text { trans } \\
\text { fatty acids }\end{array}$ & II \\
\hline $\begin{array}{l}\text { Trabert et al., } \\
2010 \text { [27] }\end{array}$ & $\begin{array}{l}\text { Case-control } \\
\text { study }\end{array}$ & $\begin{array}{l}\text { The experimental group }(n=284) \text { consisted of women aged } \\
20-65 \text { years diagnosed with endometriosis and the control group } \\
(n=660) \text { consisted of healthy women }\end{array}$ & \multicolumn{2}{|c|}{$\downarrow$} & III \\
\hline $\begin{array}{l}\text { Savaris and } \\
\text { Amaral } 2011 \text { [23] }\end{array}$ & $\begin{array}{l}\text { Case-control } \\
\text { study }\end{array}$ & $\begin{array}{l}\text { The experimental group }(n=25) \text { consisted of women diagnosed } \\
\text { with stage I-IV endometriosis, the control group }(n=20) \text { consisted } \\
\text { of women with no gynecological disorders }\end{array}$ & \multicolumn{2}{|c|}{$\downarrow$} & III \\
\hline $\begin{array}{l}\text { Khanaki et al., } \\
2012 \text { [25] }\end{array}$ & $\begin{array}{l}\text { Case-control } \\
\text { study }\end{array}$ & $\begin{array}{l}\text { The experimental group }(n=46) \text { women diagnosed with stage I-IV } \\
\text { endometriosis, and the control group }(n=74) \text { consisted of women } \\
\text { with no gynecological disorders }\end{array}$ & \multicolumn{2}{|c|}{ No influence found } & III \\
\hline
\end{tabular}

$\downarrow$ decrease of endometriosis risk

$\uparrow$ increase of endometriosis risk

*Levels of Evidence adopted by the North American Spine Society January 2005

\section{FISH OILS AND POLYUNSATURATED FATTY ACIDS (PUFAS)}

The largest study concerning consumption of fats and risk of developing endometriosis was conducted in the USA (Tab. 2) [11]. Palmitic acid was one of the unsaturated fats with consumption linked to higher endometriosis risk. Similarly, consumption of large amounts of trans-unsaturated fatty acid was also linked to an increased risk of endometriosis. In contrast, consumption of the Omega-3 fatty acids decreased the risk of developing endometriosis. For every $1 \%$ of energy that came from the Omega- 3 polyunsaturated fatty acids, and not from the trans fats, decreased the risk of endometriosis by almost 50\%. In addition, in the 2011 study by Savaris and Amaral described above, the control group had higher consumption of Omega- 3 and Omega- 6 polyunsaturated fatty acids as compared to women with endometriosis, which was likely an important factor in the observed decreased endometriosis risk [23].
A case-control population-based study conducted in the USA by Trabert et al. in 2010 evaluated dietary factors that influence risk of developing endometriosis [22]. An inverse correlation was observed between the consumption of the saturated fatty acids, monounsaturated fatty acids, and trans fats and the risk of endometriosis. Contrary to the findings of Missmer et al. (2010) [11], Trabert et al. (2010) [22] found that the increased consumption of fat in general was connected with lower risk of endometriosis. However, in this case the control group ate less calories, less fat in general, and less total cholesterol compared to women with diagnosed endometriosis.

In studies by Parazzini et al. (2004) [21] and Heilier et al. (2006) [24], no correlation was found between consumption of fish and risk of developing endometriosis. In a cross-sectional study Khanaki et al. (2012) [25] the link between endometriosis risk and level of phospholipids in the blood serum was examined. There was no correlations between 
disease severity and phospholipids level in the blood. It seems that it is not the level of phospholipids in the blood serum that is a risk factor for the disease, but rather the relationship between Omega- 3 and Omega- 6 fatty acids. In the study, the relationship between the eicosapentaenoic acid (EPA) and arachidonic acid (AA) was an important factor in endometriosis severity. Only the level of stearic acid was different and it was highest in the control group $(p=0.030)$ [25].

Šesti et al. (2007) [26] conducted a randomized comparative study in order to examine the rapidity of recurrence of endometriosis after surgical treatment by laparoscopy. After the operation, women were divided into four different groups that were observed for 6 months (Tab. 2). After 18 months, no significant differences were observed in frequency of endometriosis incidents between the three groups and the placebo group. In a study from 2009 [27] decrease in pain after surgical treatment of endometriosis was examined in four groups. It was found that after 12 months, the groups treated with hormones and dietary supplements, including Omega-3 and Omega-6 polyunsaturated fatty acids, had less pain during the menstruation compared to the control group. In constrat, Britton et al. [28] found that consumption of vegetable fats and monounsaturated and polyunsaturated fatty acids increases the risk of developing an endometrial tumor.

\section{RED MEAT}

In three studies by Parazzini et al. (2004) [21], Heilier et al. (2006) [24], and Trabert et al. (2010) [22] (Tab. 3), the risk of endometriosis was examined in reference to weekly consumption of products made of red meat and butter as the main sources of the saturated fatty acids. Parazzini et al. (2004) [21] showed that the consumption of ham, beef, and other kinds of red meat was connected with considerably higher endometriosis risk. However, no connection between the consumption of butter and developing endometriosis was found.

\section{SOY AND PHYTOESTROGENS}

Due to the connection between endometriosis and estrogens level it is possible that consumption of soy, or phytoestrogens in general, included in food could be connected with a higher risk of developing endometriosis. Consumption of soy is common in Japan and south-western Asia. Therefore, a case-control study evaluating this relationship was conducted in Japan on a population of 138 women, among whom 79 were diagnosed with endometriosis. Significant correlation between higher level of isoflavones [genistein ( $p=0.01)$ and daidzein $(p=0.007)$ ] in the urine and occurrence of endometriosis was demonstrated in the group of women suffering from advanced endometriosis (stage III-IV), but not in the group of women with stage I-II endometriosis [29].

\section{DAIRY PRODUCTS AND VITAMIN D}

In a study by Harris et al. published in 2013 [30] (Tab. 4), the general consumption of milk and other low fat dairy products was linked to a lower risk of developing endometriosis. For women who consumed more than three portions of dairy products per day, the risk of endometriosis occurrence was $18 \%$ lower than for women who consumed two or fewer portions of dairy products per day. Moreover it was discovered that the concentration of $25(\mathrm{OH})$ vitamin $D$ is inversely related with endometriosis risk. Women with the highest concentration of vitamin D had $24 \%$ less risk of developing endometriosis than the women with the lowest concentration of this vitamin. These results suggest that higher serum concentrations of $25(\mathrm{OH})$ vitamin $\mathrm{D}$ and higher consumption of dairy products are connected with lower risk of developing endometriosis.

Table 3. Influence of consumption of the red meat on the risk of developing endometriosis

\begin{tabular}{|c|c|c|c|c|}
\hline Author [ref] & Study type & Subjects & Findings & $\begin{array}{l}\text { Level of } \\
\text { evidence* }\end{array}$ \\
\hline $\begin{array}{l}\text { Parazzini et al., } \\
2004 \text { [21] }\end{array}$ & Case-control study & $\begin{array}{l}\text { The experimental group }(n=504) \text { consisted of women } \\
\text { aged } 20-65 \text { years with confirmed endometriosis and } \\
\text { the control group }(n=504) \text { consisted of women aged } \\
20-61 \text { years with no gynecological disorders }\end{array}$ & $\uparrow$ & III \\
\hline Trabert et al., 2010 [22] & Case-control study & $\begin{array}{l}\text { The experimental group }(n=284) \text { consisted of women } \\
\text { aged } 20-65 \text { years diagnosed with endometriosis and the } \\
\text { control group }(n=660) \text { consisted of healthy women }\end{array}$ & No influence found & III \\
\hline Heilier et al., 2006 [24] & Case-control study & $\begin{array}{l}\text { The experimental group }(n=176) \text { women with the } \\
\text { diagnosed endometriosis and endometrial nodules, and } \\
\text { the control group }(n=88) \text { consisted of women without } \\
\text { endometriosis }\end{array}$ & No influence found & III \\
\hline
\end{tabular}


Table 4. Influence of consumption of dairy products containing vitamin D on the occurrence of endometriosis

\begin{tabular}{|c|c|c|c|c|}
\hline Author [ref] & Study type & Subjects & Results & $\begin{array}{l}\text { Level of } \\
\text { evidence* }\end{array}$ \\
\hline $\begin{array}{l}\text { Parazzini et al., } \\
2004 \text { [21] }\end{array}$ & Case-control study & $\begin{array}{l}\text { The experimental group }(n=504) \text { consisted of women } \\
\text { aged } 20-65 \text { years with confirmed endometriosis and } \\
\text { the control group }(n=504) \text { consisted of women aged } \\
20-61 \text { years with no gynecological disorders }\end{array}$ & No influence found & III \\
\hline $\begin{array}{l}\text { Trabert et al., } \\
2010 \text { [22] }\end{array}$ & Case-control study & $\begin{array}{l}\text { The experimental group }(n=284) \text { consisted of women } \\
\text { aged } 20-65 \text { years diagnosed with endometriosis and the } \\
\text { control group }(n=660) \text { consisted of healthy women }\end{array}$ & $\downarrow$ & III \\
\hline $\begin{array}{l}\text { Heilier et al., } \\
2006 \text { [24] }\end{array}$ & Case-control study & $\begin{array}{l}\text { The experimental group }(n=176) \text { consisted of women } \\
\text { diagnosed with endometriosis and endometrial nodules } \\
\text { and the control group }(n=88) \text { consisted of women who } \\
\text { did not have endometriosis }\end{array}$ & No influence found & III \\
\hline $\begin{array}{l}\text { Harris et al., } \\
2013 \text { [30] }\end{array}$ & $\begin{array}{l}\text { Prospective cohort } \\
\text { study }\end{array}$ & $\begin{array}{l}\text { The experimental group }(n=705.56) \text { consisted of women } \\
\text { aged } 25-42 \text { years including }(n=1.385) \text { women diagnosed } \\
\text { with endometriosis and the control group consisted of the } \\
\text { healthy women }\end{array}$ & $\downarrow$ & $\|$ \\
\hline
\end{tabular}

\section{ALCOHOL CONSUMPTION}

Alcohol consumption appears to be a potential risk factor of developing endometriosis. In a case-control study performed by Matalliotakis in 2008 [31], alcohol consumption was considerably higher in the group of women suffering from endometriosis $(n=535)$ than in the control group ( $n=200)$, and in the studies of Trabert et al. (2010) [22] and of Heilier et al. (2006) [24] a higher percentage of women with endometriosis consumed alcohol than in the control group. In contrast, studies by Britton et al. (2000) [28], Parrazini et al. (2004) [21], and Savaris and Amaral (2011) [23] did not present any connections between the occurrence of endometriosis and alcohol consumption.

\section{COFFEE AND PRODUCTS CONTAINING CAFFEINE}

Reports concerning the connection between consumption of coffee and caffeine and the risk of developing endometriosis are contradictory. A meta-analysis performed by Chiaffarino et al. (2014) [32] has found that, at present, evidence is insufficient to demonstrate a clear correlation between consumption of the caffeine and occurrence of the disease. In a study Lucero et al. (2001) [33], consumption of products rich in caffeine was shown to increase concentrations of estrogen and estrone. In women who consumed large amounts of caffeine daily, an increase in the concentration of sex-hormone binding globuline (SHBG) was also observed $(p=0.093)$ [33].

\section{DISCUSSION}

The literature on dietary factors and the risk of developing endometriosis is limited. The few studies conducted in this area are contradictory. On the basis of the data presented here, we can suggest that the increased consumption of vegetables $(p=0.0001)$, fruits $(p=0.002)[21]$, Omega- 3 fatty acids $(p=0.045)$ [25], $(p=0.001)$ [11], Omega- 6 fatty acids $(p=0.006)[25]$, fats $(p=0.12)$ [27], soy and phytoestrogens [29] as well as dairy products rich in calcium $(p=0,001)$ and vitamin $D(p=0.003)$ [31] decreases the risk of developing endometriosis. Conversely, factors identified to increase the risk for endometriosis include fruits $(p=0.04)$ [22], dietary fiber $(p=0.023)[23]$, fats in general $(p=0.05)$ (including vegetable fats $(p=0.001)$, monounsaturated fats $(p=0.05)$, polyunsaturated fats $(p=0.001)$ [28], and trans-unsaturated fatty acids $(p=0.001)[11])$, pork and beef $(p=0.0004)$, ham $(p=0.001)$ [21], and alcohol $(p=0.003)$ [31].

It appears that in developing endometriosis antioxidants, vitamins $A, C$, and $E$, and B-group vitamins as well as folic acid also play an important role. Consumption of these vitamins and antioxidants decreases the risk of developing endometriosis, potentially by influencing oxidative stress and steroid hormone metabolism in the body. From 1991 to 2005 a cohort study was conducted on a group of 70,617 women by Darling et al. (2013). The experimental group ( $n=1.383$ ) consisted of women with the endometriosis confirmed by laparoscopy and the control group ( $n=69.234$ ) consisted of the healthy women. On the basis of a questionnaire concerning consumption of products and usage of vitamin supplements, the relationship between vitamins $C$ and $E$ as well as B-group vitamins and endometriosis risk was examined. It has been found that consumption of products rich in vitamins such as folic acid $(p=0.003)$, vitamin $C(p=0.02)$, and vitamin $E(p<0.0001)$ is inversely proportional to the risk of developing endometrio- 
sis. However, supplying these vitamins via dietary supplement had no influence on the occurrence of endometriosis [10]. This may suggest that other factors present in food may modify the risk of endometriosis [10]. A similar study was conducted in 2008 by Mier-Cabrera et al. on a group of women suffering from endometriosis $(n=83)$ compared to a control group of healthy women $(n=80)$. Disorders in blood serum were defined on the basis of a questionnaire assessing frequency of product consumption and serum testing to assess oxidant-antioxidant balance. The findings of the study showed lower consumption of vitamins A, C, and $E$, and microelements zinc and copper in the group of women with diagnosed endometriosis $(p<0.05)$ [1].

A high fat diet in which more than $45 \%$ of daily calorie requirements come from fat can also increase oxidative stress and inflammation in the body, thereby increasing the risk of developing endometriosis. This finding comes from a 2016 study by Heard et al. conducted in mice in which the experimental group was on the diet of $45 \%$ of fat and the control group was on a diet of $17 \%$ of fat [34]. Another study performed on animals in 2013 by Herington et al. seems to confirm the positive influence of fish oils on decreasing the risk of developing endometriosis, demonstrating that supplementation with fish oil reduced the development of postoperative adhesions connected with endometriosis [35].

\section{CONCLUSIONS}

Dietary factors that may decrease the risk of endometriosis include consumption of vegetables, antioxidant vitamins, B-group vitamins, dairy products rich in calcium and vitamin D, fish oils, and Omega-3 fatty acids - level of evidence II and III.

The dietary factors that may potentially increase the risk of developing endometriosis include consumption of trans unsaturated fatty acids, red meat and ham, as well as alcohol - level of evidence II and III.

Currently there are no clear connections between the diet and the risk of endometriosis. Further research is needed in order to explain the relationship between consumed foods and development of this disease.

\section{REFERENCES}

1. Mier-Cabrera J, Aburto-Soto T, Burrola-Méndez S, et al. Women with endometriosis improved their peripheral antioxidant markers after the application of a high antioxidant diet. Reprod Biol Endocrinol. 2009; 7: 54, doi: 10.1186/1477-7827-7-54, indexed in Pubmed: 19476631.

2. Donnez J, Squifflet J, Casanas-Roux F, et al. Typical and subtle atypical presentations of endometriosis. Obstet Gynecol Clin North Am. 2003; 30(1): 83-93, viii, indexed in Pubmed: 12699259.

3. Vinatier D, Orazi G, Cosson M, et al. Theories of endometriosis. Eur J Obstet Gynecol Reprod Biol. 2001; 96(1): 21-34, indexed in Pubmed: 11311757.

4. Basta A, Brucka A, Górski J, et al. Polish Gynocologic Society Experts Group. [The statement of Polish Society's Experts Group concerning diagnostics and methods of endometriosis treatment]. Ginekol Pol. 2012; 83(11): 871-876, indexed in Pubmed: 23379199.

5. Bulletti C, Coccia ME, Battistoni $\mathrm{S}$, et al. Endometriosis and infertility J Assist Reprod Genet. 2010; 27(8): 441-447, doi: 10.1007/s10815-0109436-1, indexed in Pubmed: 20574791.

6. Bianconi L, Hummelshoj L, Coccia ME, et al. Recognizing endometriosis as a social disease: the European Union-encouraged Italian Senate approach. Fertil Steril. 2007; 88(5): 1285-1287, doi: 10.1016/j.fertnstert.2007.07.1324, indexed in Pubmed: 17991515.

7. Missmer SA, Chavarro JE, Malspeis S, et al. A prospective study of dietary fat consumption and endometriosis risk. Hum Reprod. 2010; 25(6): 15281535, doi: 10.1093/humrep/deq044, indexed in Pubmed: 20332166.

8. Menakaya U, Infante F, Condous G. Consensus on current management of endometriosis. Hum Reprod. 2013; 28(11): 3162-3163, doi: 10.1093/humrep/det346, indexed in Pubmed: 24014606.

9. Simoens S, Dunselman G, Dirksen C, et al. The burden of endometriosis: costs and quality of life of women with endometriosis and treated in referral centres. Hum Reprod. 2012; 27(5): 1292-1299, doi: 10.1093/humrep/des073, indexed in Pubmed: 22422778.

10. Darling AM, Chavarro JE, Malspeis S, et al. A prospective cohort study of Vitamins $B, C, E$, and multivitamin intake and endometriosis. J Endometr. 2013; 5(1): 17-26, doi: 10.5301/je.5000151, indexed in Pubmed: 24511373.

11. Missmer SA, Chavarro JE, Malspeis S, et al. A prospective study of dietary fat consumption and endometriosis risk. Hum Reprod. 2010;25(6): 15281535, doi: 10.1093/humrep/deq044, indexed in Pubmed: 20332166.

12. Chang SF, Chuang Mh. Factors that affect self-care behaviour of female high school students with dysmenorrhoea: a cluster sampling study. Int J Nurs Pract. 2012; 18(2): 117-124, doi: 10.1111/j.1440-172X.2012.0200 7.x, indexed in Pubmed: 22435974.

13. Ozerdogan N, Sayiner D, Ayranci U, et al. Prevalence and predictors of dysmenorrhea among students at a university in Turkey. Int J Gynaecol Obstet. 2009; 107(1): 39-43, doi: 10.1016/j.ijgo.2009.05.010, indexed in Pubmed: 19539288.

14. Stefansson H, Geirsson RT, Steinthorsdottir V, et al. Genetic factors contribute to the risk of developing endometriosis. Hum Reprod. 2002; 17(3): 555-559, indexed in Pubmed: 11870102.

15. Whitehill K, Yong PJ, Williams C. Clinical predictors of endometriosis in the infertility population: is there a better way to determine who needs a laparoscopy? J Obstet Gynaecol Can. 2012; 34(6): 552-557, indexed in Pubmed: 22673171.

16. Fjerbaek A, Knudsen UB. Endometriosis, dysmenorrhea and diet--what is the evidence? Eur J Obstet Gynecol Reprod Biol. 2007; 132(2): 140-147, doi: 10.1016/j.ejogrb.2006.12.006, indexed in Pubmed: 17210218.

17. Tsubura A, Uehara N, Kiyozuka Y, et al. Dietary factors modifying breast cancer risk and relation to time of intake. J Mammary Gland Biol Neoplasia. 2005; 10(1): 87-100, doi: 10.1007/s10911-005-2543-4, indexed in Pubmed: 15886889.

18. Littman AJ, Beresford SA, White E. The association of dietary fat and plant foods with endometrial cancer (United States). Cancer Causes Control. 2001; 12(8): 691-702, indexed in Pubmed: 11562109.

19. La Rocca $C$, Mantovani A. From environment to food: the case of PCB. Ann Ist Super Sanita. 2006; 42(4): 410-416, indexed in Pubmed: 17361063.

20. Grassi P, Fattore $E$, Generoso $C$, et al. Polychlorobiphenyls (PCBs), polychlorinated dibenzo-p-dioxins (PCDDs) and dibenzofurans (PCDFs) in fruit and vegetables from an industrial area in northern Italy. Chemosphere. 2010; 79(3): 292-298, doi: 10.1016/j.chemosphere.2010.01.028, indexed in Pubmed: 20153014.

21. Parazzini F, Chiaffarino F, Surace $M$, et al. Selected food intake and risk of endometriosis. Hum Reprod. 2004; 19(8): 1755-1759, doi: 10.1093/humrep/deh395, indexed in Pubmed: 15254009.

22. Trabert $B$, Peters $U$, De Roos AJ, et al. Diet and risk of endometriosis in a population-based case-control study. Br J Nutr. 2011; 105(3): 459-467, doi: 10.1017/S0007114510003661, indexed in Pubmed: 20875189.

23. Savaris AL, do Amaral VF. Nutrient intake, anthropometric data and correlations with the systemic antioxidant capacity of women with pelvic endometriosis. Eur J Obstet Gynecol Reprod Biol. 2011; 158(2): 314-318, doi: 10.1016/j.ejogrb.2011.05.014, indexed in Pubmed: 21700380.

24. Heilier JF, Donnez J, Nackers $F$, et al. Environmental and host-associated risk factors in endometriosis and deep endometriotic nodules: a matched case-control study. Environ Res. 2007; 103(1): 121-129, doi: 10.1016/j.envres.2006.04.004, indexed in Pubmed: 16781705.

25. Khanaki K, Nouri M, Ardekani AM, et al. Evaluation of the relationship between endometriosis and omega- 3 and omega- 6 polyunsaturated fatty acids. Iran Biomed J. 2012; 16(1): 38-43, indexed in Pubmed: 22562031. 
26. Sesti F, CapozzoloT, Pietropolli A, et al. Hormonal suppression treatment or dietary therapy versus placebo in the control of painful symptoms after conservative surgery for endometriosis stage III-IV. A randomized comparative trial. Fertil Steril. 2007; 88(6): 1541-1547, doi: 10.1016/j. fertnstert.2007.01.053, indexed in Pubmed: 17434511.

27. Sesti F, CapozzoloT, Pietropolli A, et al. Recurrence rate of endometrioma after laparoscopic cystectomy: a comparative randomized trial between post-operative hormonal suppression treatment or dietary therapy vs. placebo. Eur J Obstet Gynecol Reprod Biol. 2009; 147(1): 72-77, doi: 10.1016/j.ejogrb.2009.07.003, indexed in Pubmed: 19665279.

28. Britton JA, Westhoff $C$, Howe GR, et al. Diet and benign ovarian tumors (United States). Cancer Causes Control. 2000; 11(5): 389-401, indexed in Pubmed: 10877332

29. Tsuchiya M, Miura T, Hanaoka T, et al. Effect of soy isoflavones on endometriosis: interaction with estrogen receptor 2 gene polymorphism. Epidemiology. 2007; 18(3): 402-408, indexed in Pubmed: 17474167.

30. Harris HR, Chavarro JE, Malspeis S, et al. Dairy-food, calcium, magnesium, and vitamin D intake and endometriosis: a prospective cohort study. Am J Epidemiol. 2013; 177(5): 420-430, doi: 10.1093/aje/kws247, indexed in Pubmed: 23380045
31. Matalliotakis IM, Cakmak H, Fragouli YG, et al. Epidemiological characteristics in women with and without endometriosis in the Yale series. Arch Gynecol Obstet. 2008; 277(5):389-393, doi: 10.1007/s00404-007-0479-1, indexed in Pubmed: 17922285

32. Chiaffarino F, Bravi F, Cipriani S, et al. Coffee and caffeine intake and risk of endometriosis: a meta-analysis. Eur J Nutr. 2014; 53(7): 1573-1579, doi: 10.1007/s00394-014-0662-7, indexed in Pubmed: 24481690.

33. Lucero J, Harlow BL, Barbieri RL, et al. Early follicular phase hormone levels in relation to patterns of alcohol, tobacco, and coffee use. Fertil Steril. 2001; 76(4): 723-729, indexed in Pubmed: 11591405.

34. Heard ME, Melnyk SB, Simmen FA, et al. High-Fat Diet Promotion of Endometriosis in an Immunocompetent Mouse Model is Associated With Altered Peripheral and Ectopic Lesion Redox and Inflammatory Status. Endocrinology. 2016; 157(7): 2870-2882, doi: 10.1210/en.20161092, indexed in Pubmed: 27175969.

35. Herington JL, Glore DR, Lucas JA, et al. Dietary fish oil supplementation inhibits formation of endometriosis-associated adhesions in a chimeric mouse model. Fertil Steril. 2013; 99(2): 543-550, doi: 10.1016/j.fertnstert.2012.10.007, indexed in Pubmed: 23103017. 